\title{
Determination of Spatial Variability in Sunflower Production
}

\author{
Fatih BAKANOĞULLARI ${ }^{1 *}$, Ulaş AY ${ }^{1}, \quad$ Bahattin AKDEMIR ${ }^{2}$ \\ ${ }^{1}$ Atatürk Soil, Water and Agricultural Meteorology Research Institute, Republic of Turkey Ministry of \\ ${ }^{2}$ Namık Kemal University, Faculty of Agriculture, Department of Biosystems Engineering 59030
}

Tekirdag-Turkey

\begin{abstract}
Aim of this research is to determine spatial variability of soils, nutrients in soil and yield for sunflower production to assess variable rate fertilisation. Materials were sunflower field, and GNSS.. Total size of the research field was $35.8 \mathrm{ha}$. Soil samples were taken from 0-30 cm and 30-60 $\mathrm{cm}$ depths. Soil texture, saturation point (\%), $\mathrm{pH}$ at saturated soil, Lime (\%), total salinity $(\%), \mathrm{CaCO}_{3}$, organic matter, useful $\mathrm{P}\left(\mathrm{P}_{2} \mathrm{O}_{5}\right)$, useful $\mathrm{K}\left(\mathrm{K}_{2} \mathrm{O}\right)$, field capacity $(\%)$ and wilting point (\%) were determined. Soil texture was found mostly clay but clay loam and a sandy clay loam texture was also determined. Mean values and standard deviations for saturation point $57.35 \%$ and $7.44 \%, \mathrm{pH} 7.30$ and 0.66 , salt 0.07 and 0.01 , lime 7.63 and 0.68 , organic material $1.29 \%$ and $0.17 \%, \mathrm{P}_{2} \mathrm{O}_{5} 18.22$ and $2.52, \mathrm{~K}_{2} \mathrm{O} 146.05 \%$ and 30.82 , field capacity $30.34 \%$ and $4.07 \%$, and for wilting point $19.18 \%$ and 2.72 . Mean yield was $2100 \mathrm{~kg} / \mathrm{ha}$. Required fertilisers will be $285 \mathrm{~kg} / \mathrm{ha}$ Ammonium Sulphate $(21 \% \mathrm{~N})$ and $115 \mathrm{~kg} / \mathrm{ha}$ Calcium Ammonium Nitrate $(26 \% \mathrm{~N})$ for constant rate fertiliser application as conventional application. If this fertiliser is applied as variable rate; amount of fertilisers will be $115 \mathrm{~kg} / \mathrm{ha}$ Calcium Ammonium Nitrate $(26 \% \mathrm{~N})$ for whole field and $285 \mathrm{~kg} / \mathrm{ha}$ Ammonium Sulphate $(21 \% \mathrm{~N})$ should be applied for 250 ha. field size. Urea $(46 \% \mathrm{~N})$ suggested as $130 \mathrm{~kg} / \mathrm{ha}$ for 100 ha. According to the results, fertiliser requirement of the sunflower field is not constant. Fertilisation necessity is spatially determined. Fertiliser application with spatial variable rate will increase yield, quality and decrease fertilisation cost and environmental effects.

Key words: Sunflower, Precision agriculture, Spatial variability, Variable rate fertilisation
\end{abstract}

\section{INTRODUCTION}

Precision farming is environmentally friendly management method for agriculture. It is based on spatial variability of soil, water, and product specifications and to apply agricultural inputs as variable rate. Aim of this research is to determine spatial variability of soils, nutrients in soil and yield for sunflower production to assess variable rate fertilisation possibilities.

Darvish et al. (2015) examined the spatial variability of certain soil variables, e.g.; soil $\mathrm{pH}$, electrical conductivity (ECe), calcium carbonate $\left(\mathrm{CaCO}_{3}\right)$, organic matter $(\mathrm{O} . \mathrm{M})$, $\%$ cation exchange capacity (CE), gypsum content and particle size distribution develop maps and assess the spatial correlations among them. Ungor and Akdemir (2010) developed a software to create prescription maps. Ozguven and Turker (2010) worked on comparative analysis of wheat, cotton and corn production. The cost of precision farming can be covered by $16.41 \%$ yield increase in wheat production in Central Anatolia, $3.96 \%$ yield increase in cotton in Southern Anatolia, and 4.01 yield increase for corn in Combine systems for 100 ha field size in 2008.Tekin and Sindir (2013) developed and tested a centrifugal fertiliser machine control system to realize variable rate controller according to the prescription map. The system can easily adopted local made fertilisers.Topakci et al. (2010) developed a software can determine field efficiency, map files, and prepare documentation for study results. The software were tested for granule fertilization. Results from investigation that was conducted by Ion et al (2015) in Southern Romania were determined fresh and dry aboveground biomass of sunflower

\footnotetext{
* Corresponding author: fbakanogulari@gmail.com
} 
under different sowing and growing conditions varied from $62.88-81.65 \mathrm{t} / \mathrm{ha}$. and 15.95-19.52 t/ha, respectively. Estrada et al (2010) researched distribution of sunflower biomass and seed yield in saline soil of Mexico highlands, and the greatest dry matter accumulation had been obtained in the stem. Ziebell et al (2013) were determined biomass of main stem unchanged or increased as planting density increased by the results from their research "sunflower as a biofuels crop: An analysis of lignocellulosic chemical properties"

Objective of the paper is to determine spatial variability of soil and crop specifications for sunflower production. Spatial variability of the analysed parameters were used to determine fertiliser requirement.

\section{MATERIALS AND METHODS}

Research crop was sunflower to determine situation of GAP in the practice. Research field area was 38 hectares. It was shown in (Figure 1). Field operations for sunflower production were given in (Table 1).

In addition, general agricultural operations in sunflower were also determined for Thrace Region, Turkey and given in Table 2. According to the results; there 15 field operations depend on field soil texture, climate conditions. Growing of sunflower was started after harvesting wheat on July 2016 and finished by harvesting on September 2017.

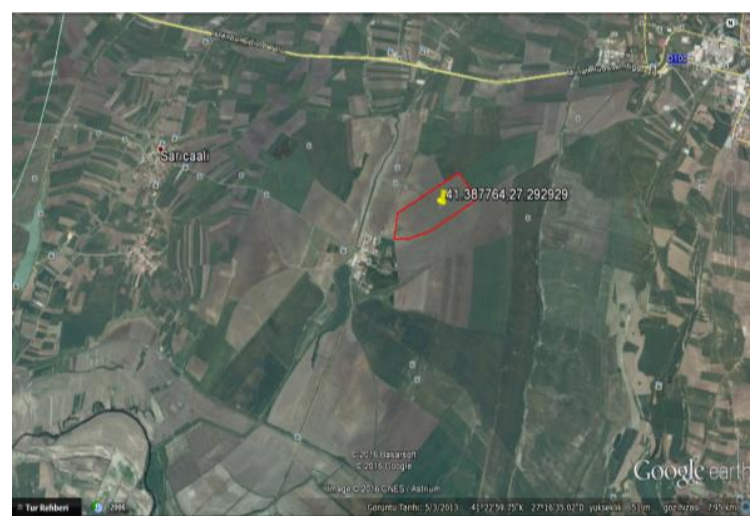

Figure 1. Experimental field in Kırklareli

In this study, soil samples from 20 points were taken from $0-30 \mathrm{~cm}$ and $30-60 \mathrm{~cm}$ depth. Soil samples were analysed for determining soil texture, saturation point $(\%), \mathrm{pH}$ at saturated soil, Lime (\%), total salinity (\%), $\mathrm{CaCO}_{3}$, organic matter, useful $\mathrm{P}\left(\mathrm{P}_{2} \mathrm{O}_{5}\right)$, useful $\mathrm{K}\left(\mathrm{K}_{2} \mathrm{O}\right)$, field capacity $(\%)$, and wilting point $(\%)$ and salinity (\%) Tuzuner (1990). In addition, changing of biomass were determined. Variety of sunflower was Limagrain LG 5542. Samples of biomass were determined for each two weeks during growing season. Number of plants for each sample was 6 plant $/ \mathrm{m}^{2}$ because sunflower planted at $70 \mathrm{~cm}$ between rows and $25 \mathrm{~cm}$ on rows. Plants were dried in a heating and drying oven 48 hour at $65^{\circ} \mathrm{C}$. Biomass was measured for wet and dried plant stems and roots. Results measured as $\mathrm{kg} / \mathrm{m}^{2}$ but presented as $\mathrm{t} / \mathrm{ha}$.

Soil samples were taken from $0-30 \mathrm{~cm}$ and $30-60 \mathrm{~cm}$ from the field. Sampling points and elevation of the field were given in Figure 2.

Table 1. Sunflower field operations

\begin{tabular}{lll}
\hline \multirow{2}{*}{ Planting } & Date & $18 / 04 / 2015$ \\
& & \\
& Sowing rate & Between rows: $70 \mathrm{~cm}$, on row: $25 \mathrm{~cm}$ \\
Fertilisation & Date & $15 / 04 / 2015$ \\
& Fertiliser & $20-20-0(\mathrm{~N}-\mathrm{P}-\mathrm{K})$ \\
& Fertilisation rate & $170 \mathrm{~kg} / \mathrm{ha}$ \\
Spraying & Date & $29 / 05 / 2015$ \\
& Herbicide & IMAZAMOX \\
\hline Harvest & Rate & $2.01 / \mathrm{ha}$ \\
\hline
\end{tabular}



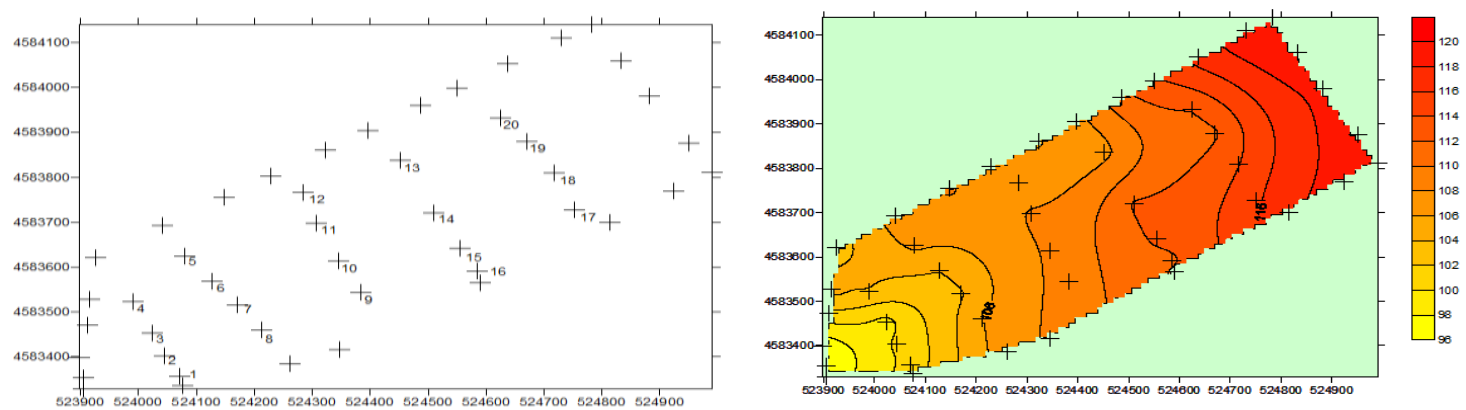

Figure 2. Sampling points and elevation map in the field

Table 2. Sunflower mechanization

\begin{tabular}{|c|c|c|c|c|c|c|c|}
\hline $\begin{array}{l}\text { Field } \\
\text { operations }\end{array}$ & Month & $\begin{array}{l}\text { Width } \\
\text { (m) }\end{array}$ & $\begin{array}{l}\text { Speed } \\
(\mathrm{km} / \mathrm{h}\end{array}$ & $\begin{array}{c}\text { Efficiency } \\
(\%)\end{array}$ & $\begin{array}{c}\text { Effective } \\
\text { Capacity } \\
\text { (ha/h) }\end{array}$ & $\begin{array}{c}\text { Average } \\
\text { Fuel } \\
\text { Consumption } \\
(\mathrm{l} / \mathrm{ha})\end{array}$ & $\begin{array}{c}\text { Man } \\
\text { labour } \\
\text { requirement } \\
\text { (h/ha) }\end{array}$ \\
\hline Plough & July & 1.40 & 6 & 0.80 & 0.67 & 30.00 & 1.190 \\
\hline Disc Harrow & August & 3.00 & 9 & 0.85 & 2.30 & 12.00 & 0.370 \\
\hline Sprayer & $\begin{array}{l}\text { August- } \\
\text { September }\end{array}$ & 16.00 & 14 & 0.65 & 14.56 & 3.50 & 0.045 \\
\hline Disc Harrow & September & 3.00 & 9 & 0.85 & 2.30 & 12.00 & 0.370 \\
\hline Rotary tiller & September & 3.00 & 5 & 0.85 & 1.28 & 25.00 & 0.667 \\
\hline $\begin{array}{l}\text { Fertiliser } \\
\text { spreader }\end{array}$ & September & 16.00 & 14 & 0.70 & 15.68 & 3.50 & 0.045 \\
\hline Harrow & September & 4.00 & 15 & 0.85 & 5.10 & 4.50 & 0.167 \\
\hline Roller-packer & September & 5.00 & 12 & 0.85 & 5.10 & 4.50 & 0.167 \\
\hline $\begin{array}{l}\text { Sowing } \\
\text { machine }\end{array}$ & October & 3.00 & 7 & 0.65 & 1.37 & 12.00 & 0.476 \\
\hline Roller-packer & October & 5.00 & 12 & 0.85 & 5.10 & 4.50 & 0.167 \\
\hline $\begin{array}{l}\text { Fertiliser } \\
\text { spreader }\end{array}$ & December & 16.00 & 14 & 0.70 & 15.68 & 3.50 & 0.045 \\
\hline Sprayer & February & 16.00 & 14 & 0.65 & 14.56 & 3.50 & 0.045 \\
\hline $\begin{array}{l}\text { Fertiliser } \\
\text { spreader }\end{array}$ & March & 16.00 & 14 & 0.70 & 15.68 & 3.50 & 0.045 \\
\hline Sprayer & March & 16.00 & 14 & 0.65 & 14.56 & 3.50 & 0.045 \\
\hline Harvesting & May-June & 5.20 & 8 & 0.70 & 2.91 & 20.00 & 0.240 \\
\hline TOTAL & & & & & & 145.50 & 4.082 \\
\hline
\end{tabular}

\section{RESULTS AND DISCUSSION}

Soil texture, saturation point $(\%), \mathrm{pH}$ at saturated soil, Lime (\%), total salinity (\%), $\mathrm{CaCO}_{3}$, organic matter, useful $\mathrm{P}\left(\mathrm{P}_{2} \mathrm{O}_{5}\right)$, useful $\mathrm{K}\left(\mathrm{K}_{2} \mathrm{O}\right)$. Soil analysis results were given in Table 3 . These results were used to create spatial variability maps.

Results of soil analyses for 0-30 cm depth were given in (Table 3). and 30-60 $\mathrm{cm}$ in (Table 4). According to the results; soil texture was generally determined as Clay but there also were Sand-Clay-Loam and ClayLoam soil textures in the research field. Mean values and standard deviations for saturation point $57.35 \%$ and $7.44 \%, \mathrm{pH} 7.30$ and 0.66 , Salt 0.07 and 0.01 , lime 7.63 and 0.68 , organic material $1.29 \%$ and $0.17 \%$, able 3. Soil analyses results for $0-30 \mathrm{~cm}$ soil depth $\mathrm{P}_{2} \mathrm{O}_{5} 18.22$ and $2.52, \mathrm{~K}_{2} \mathrm{O} 146.05 \%$ and 30.82 , field capacity $30.34 \%$ and $4.07 \%$, and for wilting point $19.18 \%$ and 2.72 .

According to the results: Soil texture was mostly clay but clay loam and sandy clay loam textures were also determined. Mean values and standard deviations were calculated a $57.35 \%$ and $7.44 \%$ for 


\begin{tabular}{|c|c|c|c|c|c|c|c|c|c|c|c|c|c|}
\hline \multirow[b]{2}{*}{$\begin{array}{c}\text { Sample } \\
\text { no }\end{array}$} & \multirow[b]{2}{*}{$\begin{array}{c}\text { Saturation } \\
\%\end{array}$} & \multirow[b]{2}{*}{$\mathrm{pH}$} & \multirow[b]{2}{*}{$\begin{array}{c}\text { Salinity } \\
\%\end{array}$} & \multirow{2}{*}{$\begin{array}{c}\text { Lime } \\
\% \\
\mathrm{CaCO}_{3}\end{array}$} & \multirow{2}{*}{$\begin{array}{c}\text { Organic } \\
\text { Matter } \\
\%\end{array}$} & \multicolumn{2}{|c|}{ Useful } & \multicolumn{3}{|c|}{ Texture } & \multirow[b]{2}{*}{$\begin{array}{c}\text { Texture } \\
\text { class }\end{array}$} & \multirow{2}{*}{$\begin{array}{c}\text { Field } \\
\text { capacity } \\
\%\end{array}$} & \multirow{2}{*}{$\begin{array}{c}\text { Wilting } \\
\text { point } \\
\%\end{array}$} \\
\hline & & & & & & $\begin{array}{l}\mathrm{P}_{2} \mathrm{O}_{5} \\
\mathrm{~kg} / \mathrm{da}\end{array}$ & $\begin{array}{c}\mathrm{K}_{2} \mathrm{O} \\
\mathrm{kg} / \mathrm{da}\end{array}$ & $\begin{array}{c}\% \\
\text { Clay }\end{array}$ & $\begin{array}{c}\% \\
\text { Silt }\end{array}$ & $\begin{array}{c}\% \\
\text { Sand }\end{array}$ & & & \\
\hline 1 & 56 & 7.14 & 0.06 & 5.6 & 1.64 & 17.52 & 195 & 41.67 & 14.58 & 43.75 & Clay & 36.06 & 23.96 \\
\hline 2 & 60 & 7.31 & 0.05 & 6.7 & 1.28 & 21.37 & 142 & 31.25 & 14.58 & 54.17 & $\begin{array}{l}\text { Sandy } \\
\text { clay } \\
\text { loam }\end{array}$ & 28.17 & 18.45 \\
\hline 3 & 50 & 5.96 & 0.05 & - & 1.33 & 15.77 & 166 & 31.25 & 14.58 & 54.17 & $\begin{array}{l}\text { Sandy } \\
\text { clay } \\
\text { loam }\end{array}$ & 25.35 & 17.39 \\
\hline 4 & 45 & 6.22 & 0.06 & - & 1.26 & 15.15 & 125 & 33.33 & 16.67 & 50.00 & $\begin{array}{l}\text { Sandy } \\
\text { clay } \\
\text { loam }\end{array}$ & 26.05 & 17.90 \\
\hline 5 & 47 & 6.12 & 0.05 & - & 1.15 & 16.99 & 182 & 41.67 & 20.83 & 37.50 & Clay & 33.56 & 20.74 \\
\hline 6 & 47 & 6.19 & 0.05 & - & 1.24 & 16.99 & 197 & 39.58 & 22.92 & 37.50 & $\begin{array}{l}\text { Clay } \\
\text { loam }\end{array}$ & 31.63 & 21.15 \\
\hline 7 & 46 & 6.7 & 0.07 & - & 1.42 & 16.38 & 188 & 45.83 & 18.75 & 35.42 & Clay & 36.44 & 26.42 \\
\hline 8 & 48 & 7.76 & 0.07 & 7.6 & 1.24 & 16.99 & 107 & 41.67 & 25.00 & 33.33 & Clay & 33.56 & 20.74 \\
\hline 9 & 66 & 7.67 & 0.08 & 8.3 & 1.22 & 22.07 & 188 & 45.83 & 27.08 & 27.08 & Clay & 37.08 & 20.68 \\
\hline 10 & 70 & 7.52 & 0.08 & 8.5 & 1.11 & 25.58 & 107 & 54.17 & 16.67 & 29.17 & Clay & 34.41 & 22.41 \\
\hline 11 & 62 & 7.73 & 0.07 & 8.0 & 1.74 & 20.06 & 105 & 52.08 & 20.83 & 27.08 & Clay & 31.95 & 19.37 \\
\hline 12 & 61 & 7.65 & 0.07 & 7.8 & 1.18 & 20.06 & 113 & 47.92 & 20.83 & 31.25 & Clay & 28.31 & 17.42 \\
\hline 13 & 64 & 7.61 & 0.09 & 7.8 & 1.19 & 18.83 & 145 & 52.08 & 18.75 & 29.17 & Clay & 31.95 & 19.37 \\
\hline 14 & 64 & 7.71 & 0.08 & 7.7 & 1.44 & 18.83 & 147 & 54.17 & 18.75 & 27.08 & Clay & 34.41 & 22.41 \\
\hline 15 & 61 & 7.63 & 0.08 & 7.6 & 1.34 & 17.52 & 150 & 50.00 & 18.75 & 31.25 & Clay & 25.13 & 21.38 \\
\hline 16 & 60 & 7.69 & 0.07 & 7.6 & 1.20 & 17.52 & 120 & 50.00 & 16.67 & 33.33 & Clay & 38.38 & 24.50 \\
\hline 17 & 60 & 7.83 & 0.08 & 7.8 & 1.32 & 16.38 & 137 & 47.92 & 20.83 & 31.25 & Clay & 28.31 & 17.42 \\
\hline 18 & 60 & 7.84 & 0.08 & 7.8 & 1.09 & 16.38 & 120 & 54.17 & 18.75 & 27.08 & Clay & 34.41 & 22.41 \\
\hline 19 & 60 & 7.84 & 0.08 & 7.8 & 1.21 & 16.99 & 150 & 54.17 & 20.83 & 25.00 & Clay & 36.72 & 25.56 \\
\hline 20 & 60 & 7.84 & 0.08 & 7.8 & 1.12 & 16.99 & 137 & 52.08 & 18.75 & 29.17 & Clay & 31.95 & 19.37 \\
\hline
\end{tabular}

saturation point, 7.30 and 0.66 for $\mathrm{pH}, 0.07$ and 0.01 for salt, 7.63 and 0.68 for lime, $1.29 \%$ and $0.17 \%$ for organic material, 18.22 and 2.52 for $\mathrm{P}_{2} \mathrm{O}_{5}, 146.05 \%$ and 30.82 for $\mathrm{K}_{2} \mathrm{O}$.

Results of soil analyses were given in (Table 3 in Table4) for 0-30 $\mathrm{cm}$ and 30-60 cm depth respectively.

Soil texture, saturation point $(\%), \mathrm{pH}$ at saturated soil, Lime (\%), total salinity (\%), $\mathrm{CaCO}_{3}$, organic matter, useful $\mathrm{P}\left(\mathrm{P}_{2} \mathrm{O}_{5}\right)$, useful $\mathrm{K}\left(\mathrm{K}_{2} \mathrm{O}\right)$ were investigated. Soil analysis results were given in (Table 3 ). These results were used to create map of analysed soil parameters (Figure 3).

The test area consists of Vertisols, which can be understood from soil analysis results. Vertisols is dark coloured, heavy or very heavy textured and contains low organic matter. They are usually dark brown-black with a thick, "A" horizon earth, commonly "dark reddish brown". Clay quantities often do not change or increase very little depending on depth. In our study, we have not seen any significant change in the amount of clay in samples we have taken from $30-60 \mathrm{~cm}$ depth. The $\mathrm{CaCO}_{3}$ contents of the soils were generally $5-10 \%$. Vertisols is the most suitable land for sunflower farming, which is deeply rooted in Thrace. Since the colours of vertisols in Thrace are dark, they quickly heat up and cause the surface horizons to dry quickly. Thus, in the lower horizons of the pile rooted plants growing in the vertisols, it is possible to utilize for a longer period of time than the higher water level which is higher than other soils such as sandy and loamy textures. The productivity and plant nutrient levels of the vertisols are generally good because of the low content of organic matter, all cultivated plants should be fertilized with nitrogenous fertilizer Dinc (1995). 
Table 4.Soil analyses results for $30-60 \mathrm{~cm}$ soil depth

\begin{tabular}{ccccccc}
\hline Sample & \multicolumn{3}{c}{ Texture } & & & \\
& $\%$ & $\%$ & $\%$ & Texture class & $\begin{array}{c}\text { Field } \\
\text { capacity }\end{array}$ & $\begin{array}{c}\text { Wilting } \\
\text { point. }\end{array}$ \\
& Clay & Silt & Sand & & & \\
\hline 1 & 43.75 & 14.58 & 41.67 & Clay & 34.41 & 22.71 \\
2 & 29.17 & 14.58 & 56.25 & Sandy clay loam & 22.67 & 12.53 \\
3 & 31.25 & 14.58 & 54.17 & Sandy clay loam & 27.75 & 19.47 \\
4 & 29.17 & 12.50 & 58.33 & Sandy clay loam & 24.26 & 15.69 \\
5 & 47.92 & 18.75 & 33.33 & Clay & 36.64 & 24.81 \\
6 & 39.58 & 27.08 & 33.33 & Clay & 32.09 & 22.79 \\
7 & 43.75 & 18.75 & 37.50 & Clay & 23.93 & 11.77 \\
8 & 47.92 & 20.83 & 31.25 & Clay & 21.64 & 14.70 \\
9 & 43.75 & 22.92 & 33.33 & Clay & 27.67 & 14.64 \\
10 & 52.08 & 18.75 & 29.17 & Clay & 26.25 & 14.79 \\
11 & 47.92 & 20.83 & 31.25 & Clay & 27.61 & 17.13 \\
12 & 50.00 & 20.83 & 29.17 & Clay & 23.19 & 11.06 \\
13 & 54.17 & 18.75 & 27.08 & Clay & 34.41 & 22.41 \\
14 & 50.00 & 20.83 & 29.17 & Clay & 23.19 & 11.06 \\
15 & 50.00 & 18.75 & 31.25 & Clay & 30.17 & 15.92 \\
16 & 47.92 & 16.67 & 35.42 & Clay & 26.63 & 10.95 \\
17 & 50.00 & 22.92 & 27.08 & Clay & 24.74 & 18.21 \\
18 & 47.92 & 20.83 & 31.25 & Clay & 35.94 & 23.83 \\
19 & 54.17 & 20.83 & 25.00 & Clay & 36.14 & 24.51 \\
20 & 45.83 & 16.67 & 37.50 & Clay & 36.44 & 26.42 \\
\hline
\end{tabular}

Nitrogen fertilisation was determined by using organic matter of soil samples. Other fertilisation recommended according to the $\mathrm{pH}$ values. Fertiliser with $\mathrm{P}$ and $\mathrm{K}$ don't recommended because of their contents in the samples were found too much. Fertiliser with Nitrogen was suggested as $90 \mathrm{~kg} / \mathrm{ha}$ to establish 1.1-1.2\% organic matter in research field soil Gucdemir (2006). Pure Nitrogen requirement was found constant but there were variability for soil texture and $\mathrm{pH}$. Consequently, Ammonium Sulphate fertiliser $(21 \%)$ recommended as $285 \mathrm{~kg} / \mathrm{ha}$ for field parts where $\mathrm{pH}$ were found higher than 7.0 and Urea (46\%) was recommended for the areas where $\mathrm{pH}$ lower than 7.0 Calcium Ammonium Nitrate (CAN $26 \%$ ) with first hoeing was suggested at $11.5 \mathrm{~kg} / \mathrm{ha}$ application rate for top dressing fertilisation. Fertiliser requirement was determined by using soil analysis data and spatial variability maps. Results were given in (Table 5).

Required amount of pure nitrogen $(\mathrm{N})$ was determined by using organic matter results.
Nitrogen requirement was determined as 90 $\mathrm{kg} / \mathrm{ha}$. for all field but type of the fertiliser which includes nitrogen $(\mathrm{N})$ was determined by using $\mathrm{pH}$ variability. According to the results, amount of available phosphorous $(\mathrm{P})$ and potassium $(\mathrm{K})$ were higher than required for sunflower growing. Fertilisers will be $285 \mathrm{~kg} / \mathrm{ha}$ Ammonium Sulphate $(21 \% \mathrm{~N})$ and $115 \mathrm{~kg} / \mathrm{ha}$ Calcium Ammonium Nitrate $(26 \% \mathrm{~N})$ for constant rate fertiliser application. If this fertiliser will be applied as variable rate by taking into account $\mathrm{pH}$ variability from (Table 2), type of the fertiliser will be changed. Consequently, amount of fertilisers will be $115 \mathrm{~kg} / \mathrm{ha}$ Calcium Ammonium Nitrate $(26 \% \mathrm{~N})$ for whole field and $285 \mathrm{~kg} / \mathrm{ha}$ Ammonium Sulphate $(21 \% \mathrm{~N})$ should be applied for 250 ha. field size and $130 \mathrm{~kg} / \mathrm{ha}$ Urea (\%46 N) suggested for 100 ha. When we evaluate application in the research field; application rate of 20-20-0 (N-P-K) mineral fertiliser was $170 \mathrm{~kg} / \mathrm{ha}$. Fertilisation rate was 34 $\mathrm{kg} / \mathrm{ha}$ for pure nitrogen $(\mathrm{N})$ and $34 \mathrm{~kg} / \mathrm{ha}$ for pure phosphorous. 

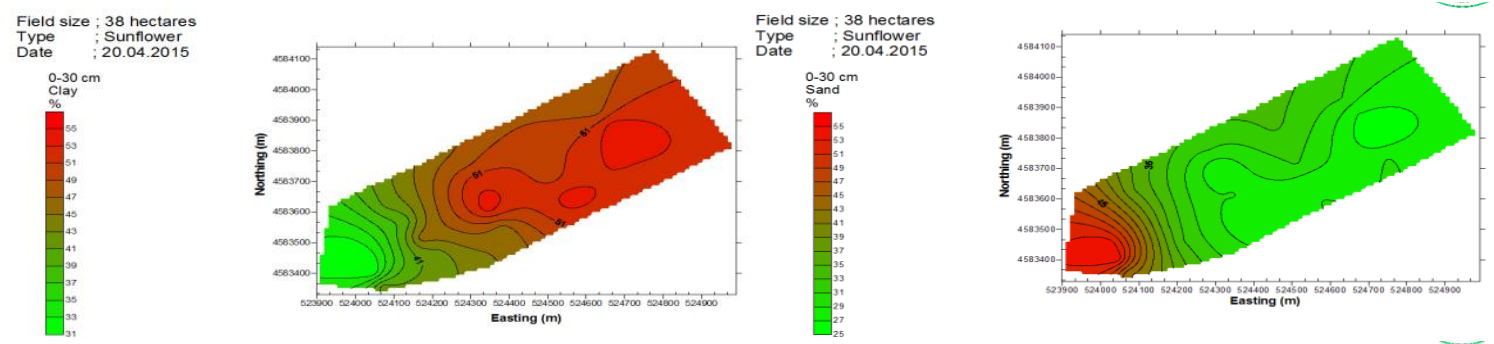

$\begin{array}{l:l}\text { Field size } & 38 \text { hectares } \\ \text { Type } & \text { Sunflower } \\ \text { Date } & 20.04 .2015\end{array}$
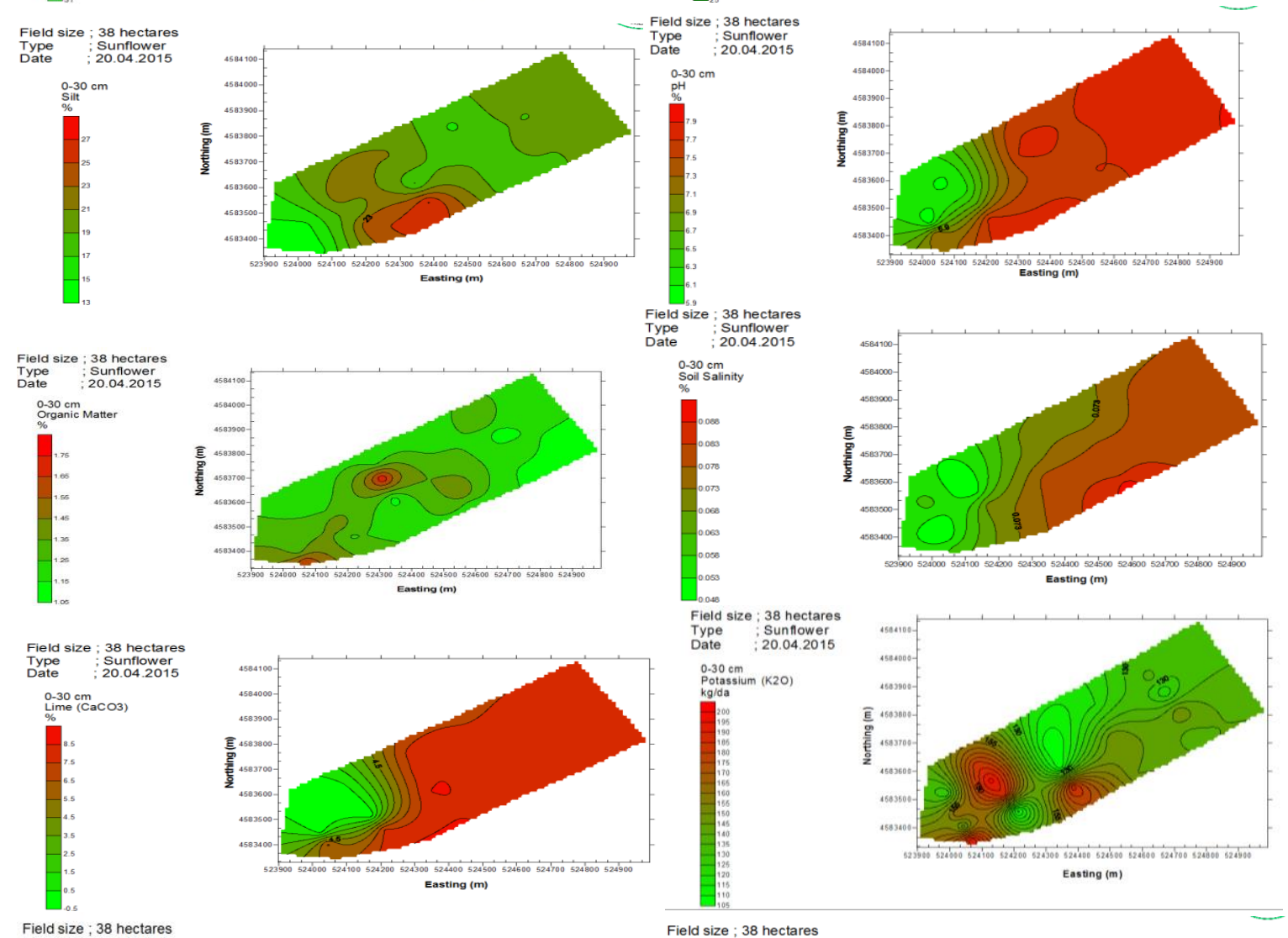

Field size : 38 hectares
Type : Sunflower
Dyte
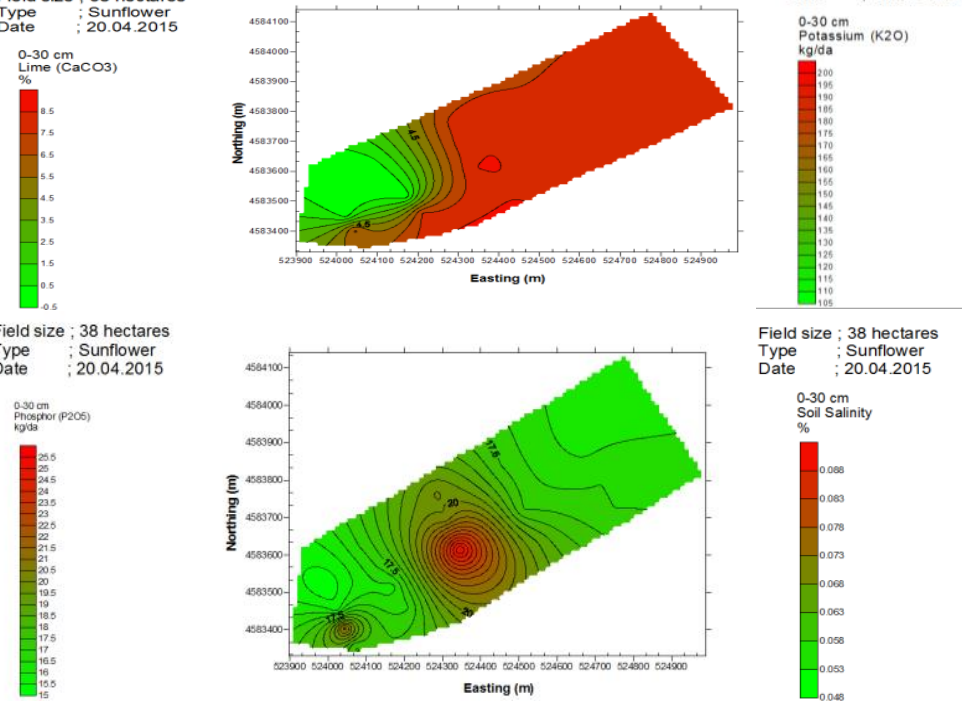

$\begin{array}{l:l}\text { Field size } & 38 \text { hectares } \\ \text { Type } ; \text { Sunflower } & \\ \text { Date } & 20.042015\end{array}$

$\quad ; 20.04$
$0.30 \mathrm{~cm}$
Soil Salinity
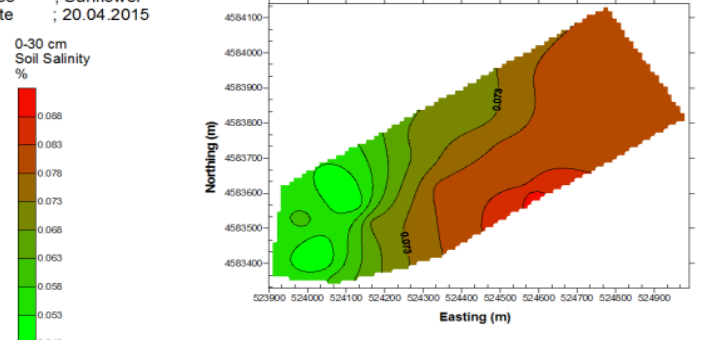

Figure 3. Spatial variability in research field soil parameters 
Table 5. Required fertiliser due to soil analysis results

\begin{tabular}{|c|c|c|c|c|c|c|c|}
\hline \multirow[t]{2}{*}{$\begin{array}{l}\text { Sample } \\
\text { number }\end{array}$} & \multicolumn{2}{|c|}{$\begin{array}{c}\text { Available } \\
\text { Nutrients** }\end{array}$} & \multicolumn{2}{|c|}{ Required pure N (kg) } & $\begin{array}{c}\text { At sowing } \\
\% 21 \text { Ammonium }\end{array}$ & $\begin{array}{l}\text { When sowing } \\
\text { Urea (\% } 46\end{array}$ & \multirow{2}{*}{$\begin{array}{c}\text { When } 1^{\text {st }} \\
\text { hoeing } \\
\% \text { 26 CAN } \\
(\mathrm{kg} / \mathrm{da})\end{array}$} \\
\hline & $\begin{array}{c}\mathrm{P}\left(\mathrm{P}_{2} \mathrm{O}_{5}\right) \\
\mathrm{kg} / \mathrm{da}\end{array}$ & $\begin{array}{c}\mathrm{K}\left(\mathrm{K}_{2} \mathrm{O}\right) \\
\mathrm{kg} / \mathrm{da}\end{array}$ & $\begin{array}{c}\text { at } \\
\text { sowing }\end{array}$ & $\begin{array}{c}\text { At } 1^{\text {st }} \\
\text { hoeing } * * *\end{array}$ & & & \\
\hline 1 & 17.52 & 195 & 6 & 3 & 28.50 & & 11.50 \\
\hline 2 & 21.37 & 142 & 6 & 3 & 28.50 & & 11.50 \\
\hline 3 & 15.77 & 166 & 6 & 3 & & 13.00 & 11.50 \\
\hline 4 & 15.15 & 125 & 6 & 3 & & 13.00 & 11.50 \\
\hline 5 & 16.99 & 182 & 6 & 3 & & 13.00 & 11.50 \\
\hline 6 & 16.99 & 197 & 6 & 3 & & 13.00 & 11.50 \\
\hline 7 & 16.38 & 188 & 6 & 3 & & 13.00 & 11.50 \\
\hline 8 & 16.99 & 107 & 6 & 3 & 28.50 & & 11.50 \\
\hline 9 & 22.07 & 188 & 6 & 3 & 28.50 & & 11.50 \\
\hline 10 & 25.58 & 107 & 6 & 3 & 28.50 & & 11.50 \\
\hline 11 & 20.06 & 105 & 6 & 3 & 28.50 & & 11.50 \\
\hline 12 & 20.06 & 113 & 6 & 3 & 28.50 & & 11.50 \\
\hline 13 & 18.83 & 145 & 6 & 3 & 28.50 & & 11.50 \\
\hline 14 & 18.83 & 147 & 6 & 3 & 28.50 & & 11.50 \\
\hline 15 & 17.52 & 150 & 6 & 3 & 28.50 & & 11.50 \\
\hline 16 & 17.52 & 120 & 6 & 3 & 28.50 & & 11.50 \\
\hline 17 & 16.38 & 137 & 6 & 3 & 28.50 & & 11.50 \\
\hline 18 & 16.38 & 120 & 6 & 3 & 28.50 & & 11.50 \\
\hline 19 & 16.99 & 150 & 6 & 3 & 28.50 & & 11.50 \\
\hline 20 & 16.99 & 137 & 6 & 3 & 28.50 & & 11.50 \\
\hline
\end{tabular}

According to the soil analyses; nitrogen application will be $90 \mathrm{~kg} / \mathrm{ha}$ and there wasn't requirement for phosphorous application for this research field. They did not applied required nitrogen. Differences between requirement and application was $56 \mathrm{~kg} / \mathrm{ha}$. There was no requirement for phosphorous (P) but applied $34 \mathrm{~kg} / \mathrm{ha}$.

Biomass measurements were started at $13^{\text {th }}$ May, 2015 and finished at $19^{\text {th }}$ August, 2015 for each two weeks (Figure 4.).

Even vegetative growing reached at maximum value in June, 2015, both wet $(63,95 \mathrm{t} / \mathrm{ha}$.$) and dry (16,19 \mathrm{t} / \mathrm{ha}$. aboveground biomass of plant reached maximum value on $5^{\text {th }}$ August, 2015 when evaluated sunflower plant growing. As the harvesting period was approached, the growth of the plant, which is the generative part of the plant, resulted in higher levels of biomass, such as table, stem and leaf, than expected from the amount of biomass from the stem and leaf before the formation of the table. 


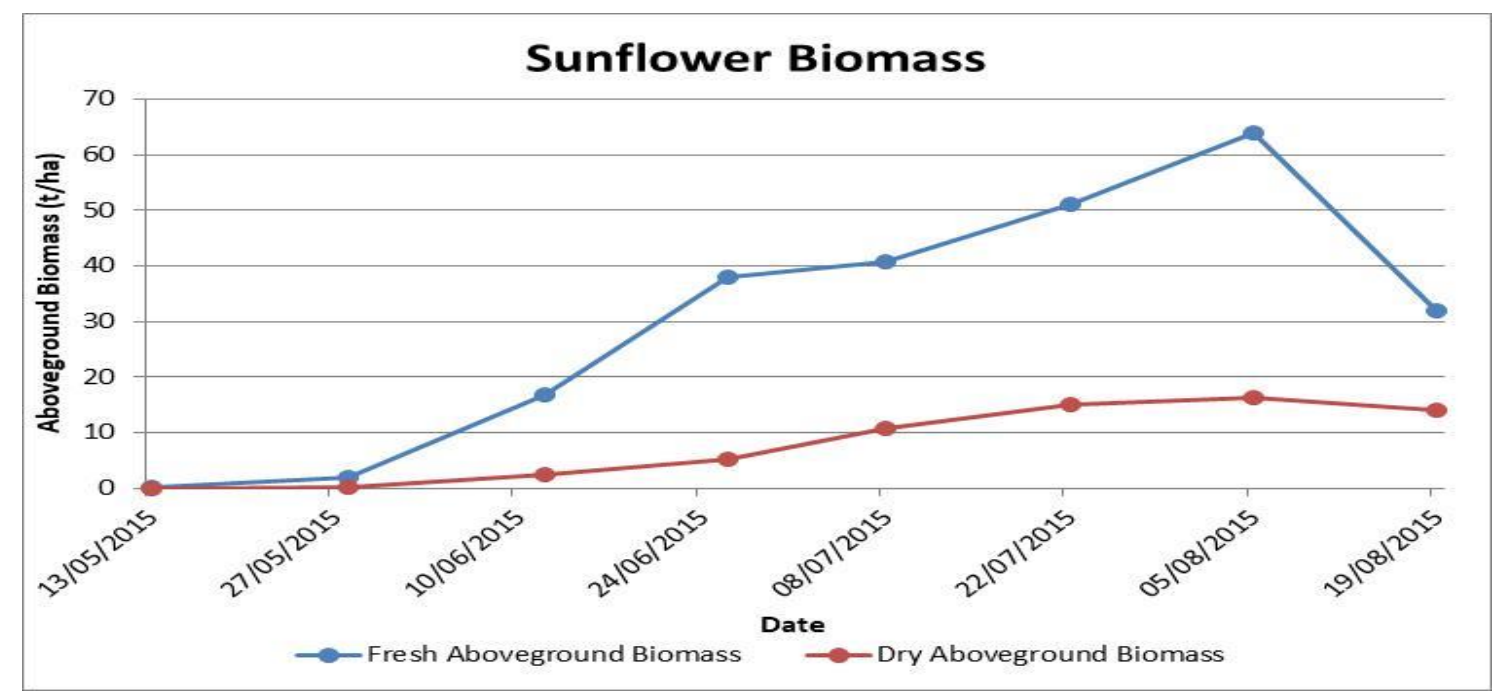

Figure. 4. Above-ground Fresh and Dry Biomass Amounts of Sunflower

\section{CONCLUSION}

Sunflower is the second important crop after wheat in Thrace Region. Determination of the spatial variability for soil properties and plant nutrients is first step of the precision farming. Variable rate application of the agricultural inputs such as fertilizer, spraying and irrigation starts with the determination of the spatial variability. In addition, spatial variability should be determined in agricultural production because it affects yield, quality and production cost (Ferrerao et al., 2013). There is always spatial variability for yield, soil specifications and quality of the productions. Farmers generally don't take into account spatial variability in the field even they know when they look their field.

Spatial variability of the soil properties and biomass were determined for sunflower growing in this research, Amount of the fertiliser requirement was affected by spatial variability of soil properties. The results showed that there was differences required and used amount of the nitrogen and phosphorous.

Determining of spatial variability requires analysing of soil, leaves and grains by laboratory analysis or sensors. These analyses also increase cost. Farmer should be careful about cost of the precision agriculture applications such as variable rate applicators and/or yield monitors. Precision agriculture applications cost

\section{ACKNOWLEDGEMENTS}

We would like to thank General Directorate of Agricultural Research and Policies (TAGEM) for support of this ICT AGRI ERA-NET project (Smart Good Agricultural Practices- Project No:16174) Additionally, we also thank Ziya Organic Agriculture Management for their cooperation.

\section{REFERENCES}

Darwish KH.M., Rashad M., Mohamed S.Z., Gada A. 2015. Spatial Distribution Analysis Of Soil Variables For Agronomic Development In El-Omayed Area, North Coastal Of Egypt, Environ Earth Scie, 74: 889-901.

Dinç U., Şenol S., Kapur S., Atalay I., Cangir C. 1995. Soils Of Turkey. Adana, Turkey.

Estrada J.A., Rodriguez-Gonzalez M.T. 2010. Sunflower Biomass Distribution and Seed Yield In Saline Soil Of Mexico Highlands, Helia, 33(52): 127-134.

Ferrero C., Mirassón H.R., Faraldo M.L., Cantamutto M.A., Arnaiz Y J.P. 2013. Spatial distribution of sunflower plants and their influence on yield in an environment of high variability, 18th ISC, Mar del Plata, Argentina, 2012 Vol.1, 
http://isasunflower.org/publication/iscsymposia/single-view/article/18thinternsunflower-conferencemar-delplata-argentina-2012.html (acess date: 24/12/2017)

Güçdemir I.H. 2006. Fertilizer And Manuring Guide of Turkey. Ankara. Turkey.

Ion V., Dicu G., Dumbrava M., Basa A.G., Temocico G., State D., Epure L.I. 2015. 15th International Multidisciplinary Scientific Geoconference. LbenaBulgaria, 67-74.

Ozguven M.M., Turker U. 2010 Application of Precision Farming in Turkey, Comparative Analysis of Wheat, Cotton and Corn production. Tartm Makinalart Bilimi Dergisi (Journal of Agricultural Machinery Science). 6(2):127-135.

Tekin B., Sindir K.O. 2013. Variable Rate Control System Designed For Spinner Disc Fertiliser Spreader-"Prefer" Scientific Journal of Agricultural Engineering 2: 45-53.

Topakci M., Ünal İ., Çanakci M., Yiğit M., Karayl D., 2010. "Improvement Of Field Efficiency Measurement System Based On GPS For Precision Agriculture Applications", Journal of Food Agriculture 8: 288-292.

Tüzüner A. 1990. Soil and Water Analysis Laboratories Manual. Ankara. Turkey.

Üngör M.G., Akdemir B. 2010 Development of a mapping programme for variable rate application, Tarım Makinalart Bilimi Derneği Dergisi 6: 121-126.

Zibell A.L., Barb J.G., Sandhu S., Moyers B.T., Sykes R.W., Doppke C., Grekom K.L., Carlile M., Marek L.F., Davis M.F., Knapp S.J., Burke J.M. 2013. Sunflower As a Biofuels Crop: An Analysis Of Lignocellulosic Chemical Properties, Biomass And Bioenergy 59: 208-217. 